\title{
The Effect of Obesity on the Severity of COVID-19: A Meta-Analysis
}

\author{
Okky Nurlita Sari, Bhisma Murti, Ignatius Loyola Sukamto
}

Masters Program in Public Health, Universitas Sebelas Maret

\section{ABSTRACT}

Background: Coronavirus Disease 2019 (COVID-19) is an infectious disease of the severe acute respiratory syndrome coronavirus 2 (SARS-CoV-2) which first appeared at the end of 2019 in the city of Wuhan, China. Obesity is one of the comorbidities that increases the risk of COVID-19 severity. This study aims to estimate the magnitude of the effect of obesity on the risk of COVID-19 severity based on similar previous primary studies.

Subjects and Method: This research is a systematic review and meta-analysis conducted by following the PRISMA flow diagram. The process of searching for articles through Google Scholar, PubMed and ScienceDirect journal databases by selecting articles published from 2020 to 2021. The keywords used include: "obesity" AND "severity" AND "COVID-19" OR "SARS-CoV-2" AND "cohort". The inclusion criteria were full paper articles, open access with a cohort study design, articles in English. PICO in this study Population: COVID-19 Patients, Intervention: Obesity, Comparison: Not Obese, and Outcome: Severity. Data were analyzed using RevMan 5.3.

Results: A total of 10 cohort studies involving 5,274 COVID-19 patients from the Americas, Europe and Asia were selected for a systematic review and meta-analysis. The results of the metaanalysis showed that obese COVID-19 patients had a 2.01 times risk of experiencing severity compared to non-obese patients $(\mathrm{aOR}=2.01 ; 95 \% \mathrm{Cl}=1.58$ to $2.57 ; \mathrm{p}<0.001)$. This meta-analysis has heterogeneity $\mathrm{I}^{2}=52 \%$, so it uses a random effect model.

Conclusion: Obesity may increase the risk of severity in hospitalized patients diagnosed with COVID-19.

Keywords: Obesity, COVID-19, SARS-CoV-2, severity

\section{Correspondence:}

Okky Nurlita Sari,. Masters Program in Public Health, Universitas Sebelas Maret. Jl. Ir. Sutami 36 A, Surakarta 57126, Jawa Tengah. Email: okkynurlithasari@gmail.com. Moobile: o82242312116.

Cite this as:

Sari ON, Murti B, Sukamto IGL (2021). The Effect of Obesity on the Severity of COVID-19: A Meta-Analysis. J Epidemiol Public Health. 06(04): 450-458. https://doi.org/10.26911/jepublichealth.2021.06.04.06.

cc (i) (-) Journal of Epidemiology and Public Health is licensed under a Creative Commons Attribution-NonCommercial-ShareAlike 4.0 International License.

\section{BACKGROUND}

At the end of 2019, precisely in December, the world was shocked by an incident that made many people nervous, namely the emergence of a new virus known as Coronavirus Disease 2019 (COVID-19) (Huang et al., 2020). The emergence of COVID-19 has attracted global attention, and on January 30, 2020 the World Health Organization (WHO) has declared COVID-19 a global pandemic with a total number of reported cases in December 2021 of approximately
271 million people exposed to COVID-19 and causing 5.32 million deaths (WHO, 2021). COVID-19 is an infectious disease of the severe acute respiratory syndrome coronavirus 2 (SARS-CoV-2) which first appeared in the city of Wuhan, China (Huang et al., 2020). Common signs and symptoms of COVID-19 infection include symptoms of acute respiratory distress such as fever, cough and shortness of breath (Dong et al., 2020). 
As many as $88 \%$ of deaths in SARS$\mathrm{CoV}-2$ positive patients are due to a history of comorbidities (Grippo et al., 2020). Patients with underlying comorbidities are more likely to contract COVID-19 and develop severe and clinically deteriorating conditions than patients without comorbidities (Dong et al., 2020). At the beginning of the COVID-19 pandemic, obesity was one of the highest comorbid factors in COVID-19 patients. Obesity as a medical condition itself has reached the stage of a pandemic. Globally there are 650 million (13\%) obese people and more than 2 billion (39\%) overweight people (WHO, 2021).

Obesity predisposes individuals to develop many conditions with other comorbiddities including hypertension, diabetes mellitus, cardiovascular disease, kidney disease and some cancers. Obesity as a comorbidity in COVID-19 patients poses a response mechanism similar to hypertension and diabetes mellitus. These mechanisms include increased proinflammatory responses and the expression of Angiotensin ConvertingEnzyme Type-2 (ACE-2) receptors that exacerbate cytokine storms. So that obesity can lead to an increased risk of severity to death in COVID-19 patients (Caussy et al., 2020; Grippo et al., 2020).

The emergence of data on the increasing prevalence of obesity among hospitalized COVID-19 patients has attracted the attention of doctors. The need for mechanical ventilator support increases in parallel with the increase in body weight or Body Mass Index (BMI) of COVID-19 patients, thus showing a strong correlation between the severity of COVID-19 and obesity (Simmonnet et al, 2020).

Meta-analysis is an epidemiological design that aims to systematically examine and combine quantitative estimation results from a number of previous studies that address the same research problem and can be combined (Mikolajewicz \& Komarova, 2019). A systematic review and meta-analysis of this study was conducted with the aim of increasing the generalizability of the findings and obtaining convincing conclusions from various similar studies regarding the effect of obesity on the severity of COVID-19. The analysis was carried out on 5,274 COVID-19 patients.

\section{SUBJECTS AND METHOD}

\section{Study Design}

The design used in this study is a systematic review and meta-analysis that uses seconddary data in the form of data obtained from previous research from the Google Scholar, ScienceDirect and PubMed databases with a range of 2020 to 2021. The search keywords used include: "obesity" OR "overweight" AND "severity" AND "COVID-19" OR "SARS-CoV-2"AND "cohort".

\section{Inclusion Criteria}

The inclusion criteria in this study were full paper and open access articles, using an observational cohort study design, the size of the relationship used with the adjusted odds ratio, the article must state that the population is patients exposed to COVID-19 who are hospitalized, the intervention used is obesity and the outcome analyzed is disease severity.

\section{Exclusion Criteria}

The exclusion criteria for this study were articles using other than English, the study was conducted with a cross sectional, case control, and Randomized Controlled Trial (RCT) design, the article did not include the adjusted odds ratio (aOR), and was published before 2020.

\section{Operational Definition of Variable} Obesity with the definition of excessive fat accumulation so that body weight is above normal with BMI 30 $\mathrm{kg} / \mathrm{m} 2$, is categorized as obese and not obese with a categorical scale. 
Severity by definition of COVID-19 progressing to stage III which is severe status with multi-organ dysfunction and cytokine storm with immune dysregulation, patient is in ICU, categorized as severe and not severe with categorical scale.

\section{Instrument Study}

The article search process is guided by the PRISMA flow diagram. The quality of the research was assessed using the Cohort Study Checklist published by the Critical Appraisal Skills Program (CASP) in 2018.

\section{Data Analysis}

The analysis in this study was carried out using the RevMan 5.3 software. The analysis was carried out on 5,274 COVID-19 patients. The results of the analysis are presented in the forest plot and the possibility of bias is presented in the funnel plot.

\section{RESULTS}

The results of the article search can be seen in Figure 1, there are 3,423 articles identified from the database used in the study. Furthermore, the deletion of duplicate data of 410 articles resulted in 3,013 filtered articles. Based on the filtered articles, there were 2,924 articles that had to be issued and 89 full text articles that met the requirements were obtained. Articles that have met the qualitative requirements were reviewed again and 10 articles were found that met the quantitative requirements and were subjected to a meta-analysis.

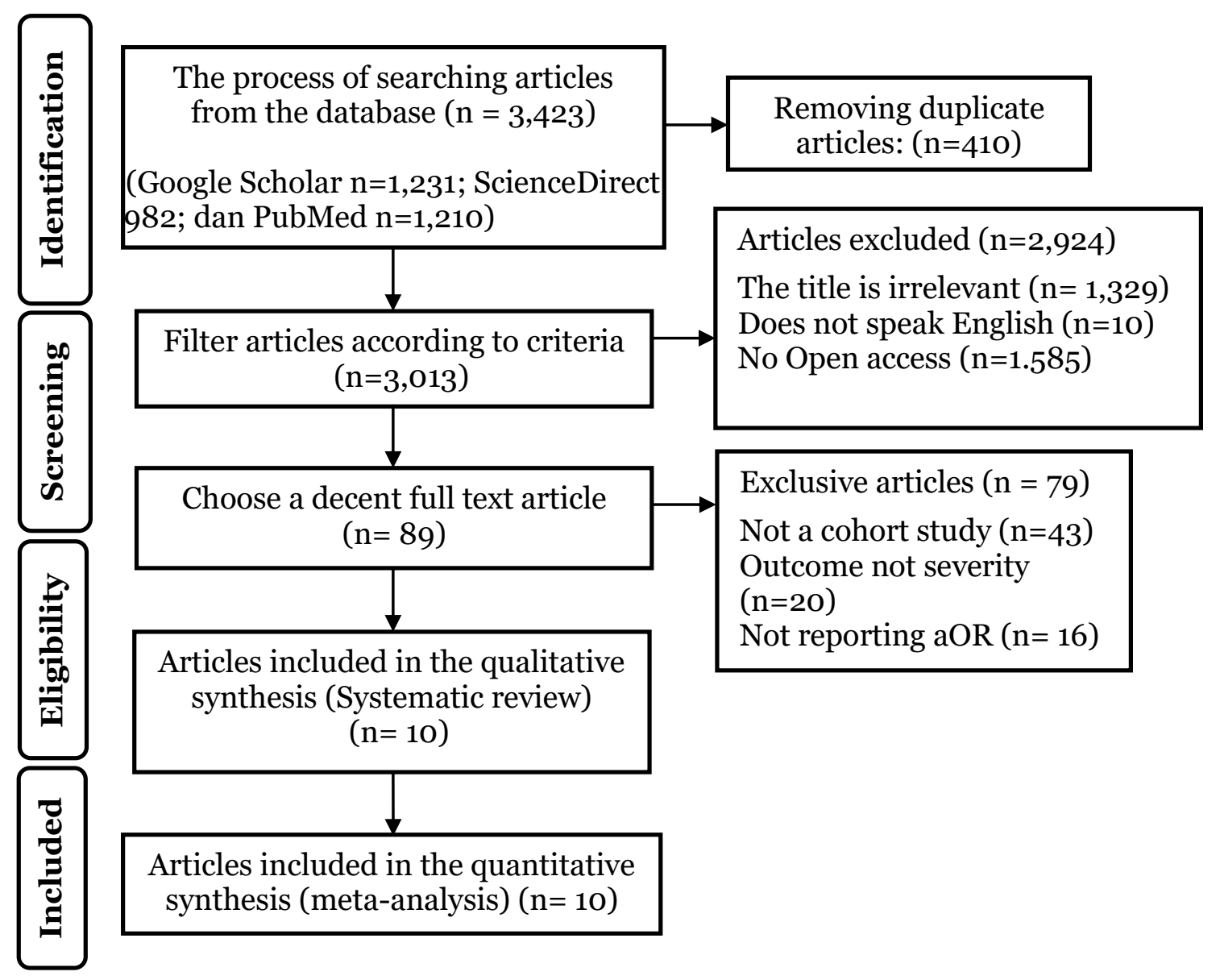

Figure 1. Search Results of Research Articles with PRISMA Flow Diagrams 
Sari et al./ Obesity on the Severity of COVID-19

Research articles come from three continents, namely America, Europe and Asia. Table 1 shows that 10 articles from the study cohort provide evidence of the influence of obesity on the severity of COVID-19. Based on the results of the analysis in Figure 2, it can be seen that as many as 10 articles report that comorbid obesity can increase the risk of severity in hospitalized patients diagnosed with COVID-19. Based on the results of the analysis there is a high heterogeneity between experiments (I2 = 52\%) so that the Random Effect Model (REM) is used. The results of this study showed that hospitalized COVID-19 patients with comorbid obesity had a 2.01 times risk of developing severe disease compared to patients without comorbid obesity (aOR $=2.01 ; 95 \% \mathrm{Cl}=1.58$ to $2.57 ; \mathrm{p}<0.001)$.

Based on Figure 3 Funnel Plot of the influence of obesity on the severity of COVID-19, the plots on the right and left sides are asymmetrical to each other and do not form an inverted funnel. The left plot has a standard error between $>0$ to $>0.2$ and the right plot has a standard error between $>0.2$ to 0.8 . This identifies that in this study there is a real bias (overestimate).

\begin{tabular}{|c|c|c|c|c|}
\hline Study or Subgroup & log[Odds Ratio] & SE & Weight & IV, Random, 95\% C \\
\hline Biscarini 2020 & 0.6729 & 0.3283 & $9.0 \%$ & $1.96[1.03,3.73$ \\
\hline Cai 2020 & 1.2238 & 0.4527 & $5.7 \%$ & $3.40[1.40,8.2$ \\
\hline Ebinger 2020 & 0.6678 & 0.2875 & $10.5 \%$ & $1.95[1.11,3$. \\
\hline Fresan 2021 & 1.2355 & 0.3248 & $9.1 \%$ & $3.44[1.82,6$. \\
\hline Hajifathalian 2020 & 0.4574 & 0.1489 & $17.8 \%$ & $1.58[1.18,2$ \\
\hline Jayanama 2021 & 1.5539 & 0.586 & $3.8 \%$ & $4.73[1.50,14$. \\
\hline Palaiodemos 2020 & 1.16 & 0.4129 & $6.6 \%$ & $3.19[1.42,7$ \\
\hline Suresh 2021 & 0.3148 & 0.1261 & $19.1 \%$ & $1.37[1.07,1$. \\
\hline Yoshida 2021 & 0.4383 & 0.175 & $16.2 \%$ & $1.10,2$ \\
\hline Zheng 2021 & 1.7527 & 0.8055 & $2.2 \%$ & $5.77[1.19,27$ \\
\hline \multicolumn{3}{|l|}{ Total $(95 \% \mathrm{Cl})$} & $100.0 \%$ & $2.01[1.58,2.5$ \\
\hline \multicolumn{5}{|c|}{ Heterogeneity: Tau $^{2}=0.07 ; \mathrm{Chi}^{2}=18.58, \mathrm{df}=9(\mathrm{P}=0.03) ; \mathrm{I}^{2}=52 \%$} \\
\hline
\end{tabular}

Figure 2. Forest Plot Effect of Obesity on the Severity of COVID-19

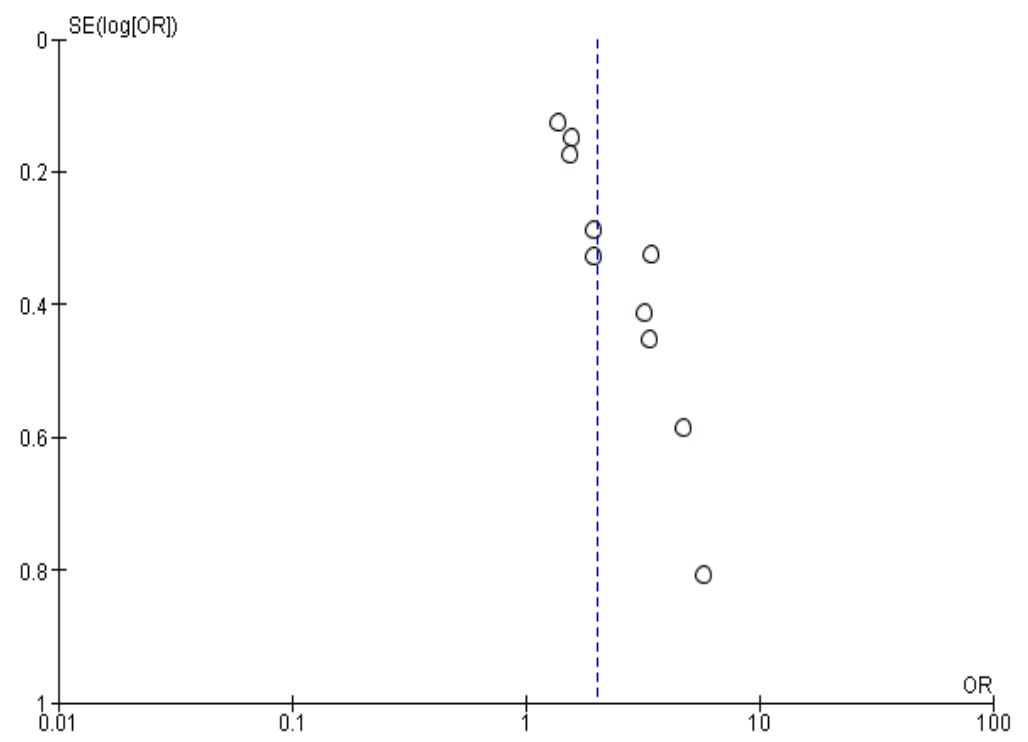

Figure 3. Funnel Plot of the Effect of Obesity on the Severity of COVID-19 
Table 1. Summary Source of the Effect of Obesity on the Severity of COVID-19

\begin{tabular}{|c|c|c|c|c|c|c|c|c|}
\hline \multirow[b]{2}{*}{$\begin{array}{l}\text { Author } \\
\text { (Year) }\end{array}$} & \multirow[b]{2}{*}{ Country } & \multirow[b]{2}{*}{$\begin{array}{l}\text { Study } \\
\text { design }\end{array}$} & \multicolumn{2}{|c|}{ Total of sample } & \multirow[b]{2}{*}{$\begin{array}{c}\text { Population } \\
\text { (P) }\end{array}$} & \multirow[b]{2}{*}{$\begin{array}{l}\text { Intervention } \\
\text { (I) }\end{array}$} & \multirow[b]{2}{*}{ Comparison (C) } & \multirow[b]{2}{*}{$\begin{array}{l}\text { Outcome } \\
\text { (O) }\end{array}$} \\
\hline & & & $\begin{array}{l}\text { Patient of } \\
\text { COVID-19 }\end{array}$ & $\begin{array}{c}\text { Patient of } \\
\text { obesity (\%) }\end{array}$ & & & & \\
\hline $\begin{array}{l}\text { Biscarini et } \\
\text { al. (2020) }\end{array}$ & $\begin{array}{l}\text { Italy } \\
\text { (Europe) }\end{array}$ & Cohort & 331 & $74(22.4 \%)$ & $\begin{array}{l}\text { COVID-19 } \\
\text { patient }\end{array}$ & $\begin{array}{l}\text { Obese COVID- } \\
19 \text { patients }\end{array}$ & $\begin{array}{l}\text { Non obese } \\
\text { COVID-19 patients }\end{array}$ & $\begin{array}{l}\text { Disease severity in } \\
\text { COVID-19 patients }\end{array}$ \\
\hline $\begin{array}{l}\text { Cai et al. } \\
(2020)\end{array}$ & China (Asia) & Cohort & 383 & $41(10.7 \%)$ & $\begin{array}{l}\text { COVID-19 } \\
\text { patient }\end{array}$ & $\begin{array}{l}\text { Obese COVID- } \\
19 \text { patients }\end{array}$ & $\begin{array}{l}\text { Non obese } \\
\text { COVID-19 patients }\end{array}$ & $\begin{array}{l}\text { Disease severity in } \\
\text { COVID-19 patients }\end{array}$ \\
\hline $\begin{array}{l}\text { Ebinger et al. } \\
\text { (2020) }\end{array}$ & $\begin{array}{l}\text { California } \\
\text { (America) }\end{array}$ & Cohort & 442 & $71(16.1 \%)$ & $\begin{array}{l}\text { COVID-19 } \\
\text { patient }\end{array}$ & $\begin{array}{l}\text { Obese COVID- } \\
19 \text { patients }\end{array}$ & $\begin{array}{l}\text { Non obese } \\
\text { COVID-19 patients }\end{array}$ & $\begin{array}{l}\text { Disease severity in } \\
\text { COVID-19 patients }\end{array}$ \\
\hline $\begin{array}{l}\text { Fresan et al. } \\
\text { (2021) }\end{array}$ & $\begin{array}{l}\text { Spain } \\
\text { (Europe) }\end{array}$ & Cohort & 176 & $10(5.7 \%)$ & $\begin{array}{l}\text { COVID-19 } \\
\text { patient }\end{array}$ & $\begin{array}{l}\text { Obese COVID- } \\
19 \text { patients }\end{array}$ & $\begin{array}{l}\text { Non obese } \\
\text { COVID-19 patients }\end{array}$ & $\begin{array}{l}\text { Disease severity in } \\
\text { COVID-19 patients }\end{array}$ \\
\hline $\begin{array}{l}\text { Hajifathalian } \\
\text { et al. (2020) }\end{array}$ & $\begin{array}{l}\text { New York } \\
\text { (America) }\end{array}$ & Cohort & 770 & $227(29.5 \%)$ & $\begin{array}{l}\text { COVID-19 } \\
\text { patient }\end{array}$ & $\begin{array}{l}\text { Obese COVID- } \\
19 \text { patients }\end{array}$ & $\begin{array}{l}\text { Non obese } \\
\text { COVID-19 patients }\end{array}$ & $\begin{array}{l}\text { Disease severity in } \\
\text { COVID-19 patients }\end{array}$ \\
\hline $\begin{array}{l}\text { Jayanama } \\
\text { et al. (2021) }\end{array}$ & $\begin{array}{l}\text { Thailand } \\
\text { (Asia) }\end{array}$ & Cohort & 147 & $46(31.3 \%)$ & $\begin{array}{l}\text { COVID-19 } \\
\text { patient }\end{array}$ & $\begin{array}{l}\text { Obese COVID- } \\
19 \text { patients }\end{array}$ & $\begin{array}{l}\text { Non obese } \\
\text { COVID-19 patients }\end{array}$ & $\begin{array}{l}\text { Disease severity in } \\
\text { COVID-19 patients }\end{array}$ \\
\hline $\begin{array}{l}\text { Palaiodemos } \\
\text { et al. (2020) }\end{array}$ & $\begin{array}{l}\text { New York } \\
\text { (America) }\end{array}$ & Cohort & 200 & $46(23.0 \%)$ & $\begin{array}{l}\text { COVID-19 } \\
\text { patient }\end{array}$ & $\begin{array}{l}\text { Obese COVID- } \\
19 \text { patients }\end{array}$ & $\begin{array}{l}\text { Non obese } \\
\text { COVID-19 patients }\end{array}$ & $\begin{array}{l}\text { Disease severity in } \\
\text { COVID-19 patients }\end{array}$ \\
\hline $\begin{array}{l}\text { Suresh et al. } \\
(2021)\end{array}$ & America & Cohort & 1.983 & $1.031(51.9 \%)$ & $\begin{array}{l}\text { COVID-19 } \\
\text { patient }\end{array}$ & $\begin{array}{l}\text { Obese COVID- } \\
19 \text { patients }\end{array}$ & $\begin{array}{l}\text { Non obese } \\
\text { COVID-19 patients }\end{array}$ & $\begin{array}{l}\text { Disease severity in } \\
\text { COVID-19 patients }\end{array}$ \\
\hline $\begin{array}{l}\text { Yoshida } \\
\text { et al. (2021) }\end{array}$ & $\begin{array}{l}\text { California } \\
\text { (America) }\end{array}$ & Cohort & 776 & $409(52.7 \%)$ & $\begin{array}{l}\text { COVID-19 } \\
\text { patient }\end{array}$ & $\begin{array}{l}\text { Obese COVID- } \\
19 \text { patients }\end{array}$ & $\begin{array}{l}\text { Non obese } \\
\text { COVID-19 patients }\end{array}$ & $\begin{array}{l}\text { Disease severity in } \\
\text { COVID-19 patients }\end{array}$ \\
\hline $\begin{array}{l}\text { Zheng } \\
\text { et al. (2021) }\end{array}$ & $\begin{array}{l}\text { China } \\
\text { (Asia) }\end{array}$ & Cohort & 66 & $45(68.2 \%)$ & $\begin{array}{l}\text { COVID-19 } \\
\text { patient }\end{array}$ & $\begin{array}{l}\text { Obese COVID- } \\
19 \text { patients }\end{array}$ & $\begin{array}{l}\text { Non obese } \\
\text { COVID-19 patients }\end{array}$ & $\begin{array}{l}\text { Disease severity in } \\
\text { COVID-19 patients }\end{array}$ \\
\hline
\end{tabular}




\section{DISCUSSION}

A systematic review and meta-analysis of this study reported that obesity may increase the risk of severity in hospitalized patients diagnosed with COVID-19 $(\mathrm{aOR}=2.01$; $95 \% \mathrm{Cl}=1.58$ to $2.57 ; \mathrm{p}<0.001)$. This is in line with a study conducted by Cai in 2020 conducted at a hospital in Shenzhen China, the study reported that obesity, especially in men, significantly increases the risk of severity of COVID-19.

A study conducted in New York City reported that obese patients with COVID-19 were more likely to come to the hospital with more severe symptoms and have an increased need for mechanical ventilation and double the risk of serious illness requiring admission to the Intensive Care Unit. (ICU) in obese COVID-19 patients (Hajifathaliaan et al., 2020).

The prevalence of obesity among COVID-19 patients was also analyzed by Caussy and colleagues in 2020, who reported a $2.8 \%$ increase in the prevalence of obesity in patients with COVID-19 admitted to the ICU. This is because obesity can change lung homeostasis and can affect respiratory health through different mechanisms, so obese COVID-19 patients must receive more intensive care (Caussy et al., 2020). ICU patients with severe COVID-19 had higher levels of Interleukin-6 (IL-6), Tumor Necrosis Factor-alpha (TNF- $\alpha$ ) than patients not admitted to the ICU, indicating the presence of a hyperinflammatory condition also known as cytokine storm.

The mortality and morbidity rates for COVID-19 patients with critical conditions in the world are quite high. The study explained that the majority of patients infected with critically ill COVID-19 had multiple organ dysfunction or multiple organ dysfunction syndrome (MODS), of which 67\% had Acute Respiratory Distress Syndrome (ARDS), 29\% had liver dysfunction,
29\% had acute kidney injury (AKI), 23\% with cardiac injury, and $2 \%$ with pneumothorax (Shang et al, 2020; Li et al., 2020). One of the triggers for the emergence of ARDS in COVID-19 patients is pneumonia. Obese patients with COVID-19 have a higher risk of severe pneumonia than normal weight COVID-19 patients (Gattinoni et al., 2020; Tay et al., 2020; Pranata et al., 2020). The outcome of ARDS patients caused by COVID-19 is worse than that of ARDS patients caused by other diseases (Gibson et al., 2020).

One of the main features of ARDS in COVID-19 is the presence of a cytokine storm. Cytokine storm is an abnormal systemic inflammatory response due to excessive production of proinflammatory cytokines and chemokines (Nile et al., 2020). Under normal conditions, the innate immune system response is the first line of defense against infection. However, an abnormal and excessive immune response can cause immune damage to the human body. An in vitro cell experiment showed that in the early stages of SARS-CoV infection there is delayed release of cytokines and chemokines by respiratory epithelial cells, dendritic cells, and macrophages. Then, cells secrete antiviral factors interferons (IFNs) and pro-inflammatory cytokines (interleukin (IL)-1 $\beta$, IL-6, and tumor necrosis factor (TNF)) and chemokines (CC motif chemokine ligand (CCL)-2, CCL. -3 , and CCL-5) in bulk. The production of IFN-I or IFN- $/ \beta$ is a key natural immune response against viral infections, and IFN-I is a key molecule that plays an antiviral role in the early stages of viral infection. Delayed release of IFN in the early stages of SARS-CoV infection precludes the body's antiviral response (Li et al., 2020; Ye et al., 2020).

The rapidly increasing cytokines and chemokines attract large numbers of inflammatory cells, such as neutrophils and 
monocytes, resulting in excessive infiltration of inflammatory cells into lung tissue, resulting in lung injury. In addition, it will also cause apoptosis of endothelial cells and epithelial cells which damage the pulmonary microvasculature and the alveolar epithelial cell barrier, resulting in vascular leakage and alveolar edema, which ultimately causes hypoxia in the body. Therefore, inflammatory mediators play a key role in the pathogenesis of ARDS (Li et al., 2020; Ye et al., 2020).

In particular, obesity was identified as a risk factor for a poor SARS-CoV-2 prognosis based on higher levels of inflammation-associated biomarkers such as IL-6 and TNF- (Jeong, Yoon, and Lee, 2020). Serum IL-6 and TNF- concentrations were predictors of increasing severity and risk of death in SARS-CoV-2 patients. Disruption of the immune response due to obesity reduces the response of cytotoxic cells to immunocompetent cells which play a major role as antivirals. ACE-2 receptors are expressed more in adipose tissue than in the lungs. Thus, obesity with an increase in adipose tissue mass causes an increase in the number of ACE-2 receptor expression. This is the reason COVID-19 patients with obesity are more at risk of increasing the severity of infection (Caci et al., 2020).

Research conducted at an Academic Hospital in Thailand showed an increase in pneumonia and severe pneumonia in patients who were overweight. Obese patients with COVID-19 have a higher risk of severe pneumonia than COVID-19 patients with normal weight (Pranata et al., 2020). Patients who have other comorbidities such as cardiovascular disease, hypertension, diabetes mellitus, and chronic kidney disease will be at higher risk for experiencing severe COVID-19. This is because obesity is associated with an increased risk of diabetes mellitus, hypertension, and cardiovas- cular disease. The greater number of comorbidities in obese patients will increase the severity of COVID-19 (Wang et al., 2020).

In this study, there are research limitations, namely the existence of publication bias, this is shown in the funnel plot, the existence of language bias because the articles used are only in English so that they ignore other languages, and there is a search bias because the database to search for articles used only 3 databases.

\section{AUTHORS CONTRIBUTION}

Okky Nurlita Sari as the main researcher who has a topic, seeks and collects research data. Bhisma Murti and Sukamto examine and analyze research data and documents.

\section{FUNDING AND SPONSORSHIP}

This study is self-funded.

\section{CONFLICT OF INTEREST}

There is no conflict of interest in this study.

\section{ACKNOWLEDGMENT}

The researchers would like to thank all those who have helped in the preparation of this article and also to the database providers including Google Scholar, PubMed, and Science Direct.

\section{REFERENCES}

Biscarini S, colaneri M, Ludovisi S, Seminari E, Pieri TC, Valsecchi P, Gallazzi I et al. (2020). The obesity paradox: Analisys from the SMAtteo COVID-19 Regestry (SMACORE) cohort. J Nutr Metab Cardiovasc Dis. 30(11): 19201925. DOI: 10.1016/j.numecd.07.047.

Caci G, Albini A, Malerba M, Noonan D, Pochetti P, Polosa R (2020). COVID19 and obesity: dangerous liaisons. J Clin Med. 9(8):1-12. DOI: 10.3390/jcm.9082511. 
Cai Q, Chen F, Wang T, Luo F, Liu X, Wu Q, He Q, Wang Z, Liu Y et al. (2020). Obesity and COVID-19 Severity in a Designated Hospital in Shenzhen, China. J. Diabetes Care. 23(7): 13921398. DOI: $10.2337 /$ dc20-0576

CASP (2018). Critical appraisal skills programme cohort study checklist. https://casp-uk.net/-wpcontent/uploads/2018/01/CASPCohort-StudyChecklist_2018.pdf. Accessed in October 3, 2021.

Caussy C, Wallet F, Laville M, Disse E (2020). Obesity is Associated with Severe Forms of COVID-19. J. Obesity. (28)7: 1175. DOI: 10.1002/oby.22842.

Dong Y, Mo X, Hu Y (2020). Epidemiology of Covid-19 Among Children in China. J. Pediatrics. 145(6). DOI: 10.1542/peds.2020-0702.

Ebinger JE, Achamallah N, Ji H, Claggett BL, Sun N, Botting P, et al. (2020) Pre-existing traits associated with Covid-19 illness severity. PLoS ONE 15(7): e0236240. DOI: 10.1371/journal.pone.0236240.

Fresán U, Guevara M, Elía F Esther Albéniz E, Burgui $\mathrm{C}$ dan Castilla $\mathrm{J}$ (2021). Independent Role of Severe Obesity as a Risk Factor for COVID19 Hospitalization: A Spanish Population-Based Cohort Study. J Obesity. 29: 29-37. DOI: 10.1002/oby.23029.

Gattinoni L, Chiumello D, Rossi S (2020). COVID-19 pneumonia: ARDS or not? Crit Care. 24(1): 1-3. DOI: 10.1186/s13054-020-02880-z

Gibson PG, Qin L, Puah SH (2020). COVID-19 acute respiratory distress syndrome (ARDS): clinical features and differences from typical preCOVID-19 ARDS. Med J Aust. 213(2): 54-56. DOI: 10.5694/mja2.50674.
Grippo F, Navarra S, Orsi C, Manno V, Grande E, Crialesi R, Frova L, Marchetti s et al. (2020). The role of COVID-19 in the death of sars-COV2-positive patients: A study based on death certificates. J Clin Med. 9(11):113. DOI: $10.3390 / \mathrm{jcm} 9113459$

Hajifathalian K, Kumar S, Newberry C, Shah S, Fortune B, Krisko $\mathrm{T}$ et al. (2020). Obesity is Associated with Worse Outcomes in COVID-19: Analysis of Early Data from New York City. J Obesity. 28: 1606-1612. DOI: 10.1002/oby.22923.

Huang C, Wang Y, Li X., Ren L, Zhao J, Hu Y, Zhang L, et al. (2020). Clinical features of patients infected with 2019 novel coronavirus in Wuhan, China. Lancet. 395(10223): 497-506. DOI: 10.1016/So140-6736(20)30183-5.

Jayanama K, Srichatrapimuk S, Thammavaranucupt K, Kirdlarp S, Suppadungsuk S, Wongsinin T, et al. (2021) The association between body mass index and severity of Coronavirus Disease 2019 (COVID-19): A cohort study. PLoS ONE 16(2): e0247023. DOI: 10.1371/journal.pone.0247023.

Jeong IK, Yoon KH, Lee MK (2020). Diabetes and COVID-19: Global and regional perspectives. J. diabetes Res Clin Pract. 166.108303. DOI: 10.1016/j.diabres.2020.108303

Li R, Liu H, Qi H, et al (2020). Lung ultrasound assessment of acute respiretory distress syndrome caused by coronavirus disease 2019: An observational study. Hong Kong J Emerg Med. DOI: 10.1177/1024907920969326.

Mikolajewicz N, Komarova SV (2019). Metaanalytic methodology for basic research: A practical guide. Fron Physiol. 10(5). DOI: 10.3389/fphys.2019.00203. 
Nile SH, Nile A, Qiu J, Li L, Jia X, Kai G (2020). COVID-19: Pathogenesis, cytokine storm and therapeutic potential of interferons. Cytokine Growth Factor Rev. 53: 66-70. DOI: 10.1016/j.cytogfr.2020.05.002.

Palaiodimosa L, Kokkinidis DG, Li W, Karamanis D, Ognibeneb $\mathrm{J}$, et al. (2020). Severe obesity, increasing age and male sex are independently associated with worse in-hospital outcomes, and higher in-hospital mortality, in a cohort of patients with COVID-19 in the Bronx, New York. J Metabolism 108: 154262. DOI: 10.1016/j.metabol.2020.154262.

Pranata R, Lim MA, Yonas E, Vania R, Lukito AA, Siswanto BB, et al. (2020). Body mass index and outcome in patients with COVID-19: A dose-response meta-analysis. J. diabret 47(2):101178. DOI: 10.1016/j.diabet.2020.07.005.

Shang Y, Pan C, Yang X, et al. (2020). Management of critically ill patients with COVID-19 in ICU: statement from frontline intensive care experts in Wuhan, China. Ann Intensive Care. 10(1): 1-24. DOI: 10.1186/s13613-02o-00689-1.

Simonnet A, Chetboun M, Poissy J, Raverdy V, Noulette J, Duhamel A, et al (2020). High prevalence of obesity in severe acute respiratory syndrome coronavirus-2 (SARS-CoV-2) requiring invasive mechanical ventilation. J Obesity (Silver Spring). 28(7):11951199. DOI: 10.1002/oby.22831.

Suresh S, Siddiqui M, Abu GM, Jou J Simmer S, Mendiratta V, Russel S, AlShammari M et al. (2021) Association of obesity with illness severity in hospitalized patients with COVID-19: A retrospective cohort study. J Obes
Res Clin Pract. 15(2): 172-176. DOI: 10.1016/J.ORCP.2021.02.006.

Tay MZ, Poh CM, Renia L, MacAry PA, Lisa (2020). The trinity of COVID-19: immunity, inflammation and intervention. Nat Rev Immunol. 20(6): 363-374. DOI: $10.1038 / \mathrm{s} 41577-020-$ 0311-8.

Wang D, Hu B, Hu C, Zhu F, Liu X, Zhang $\mathrm{J}$, et al. (2020). Clinical Characteristics of 138 Hospitalized Patients With 2019 Novel Coronavirus-Infected Pneumonia in Wuhan, China. JAMA. 323(11):1061-9. DOI: 10.1001/jama.2020.1585

WHO (2021). Coronavirus Disease (COVID-19). World Health Organization. https://covid19.who.int/. Accessed in October 1, 2021.

WHO (2021). Obesity. World Health Organization.https://www.who.int/health -topics/obesity, Accessed in October 1, 2021.

Ye Q, Wang B, Mao J (2020). The pathogenesis and treatment of the "Cytokine Storm" in COVID-19. J Infect. 80(6): 607-613. DOI: 10.1016/j.jinf.2020.03.037

Yoshida Y, Gillet SA, Brown MI, Zu Y, Wilson $S$ et al. (2021). Clinical characteristics and outcomes in women and men hospitalized for coronavirus disease 2019 in New Orleans. Biol Sex Differ. 12:20 DOI: 10.1186/s13293-O21-00359-2.

Zheng KI, Gao F, Wang XB, et al. (2020) Obesity as a risk factor for greater severity of COVID-19 in patients with metabolic associated fatty liver disease. Metabolism, 108: 154244. DOI: 10.1016/j.metabol.2020.154244. 